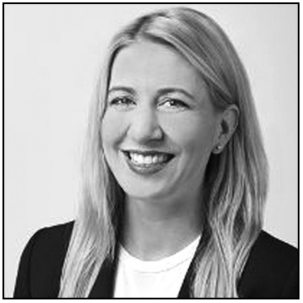

Maren Krimmer

\title{
The Yukos Arbitration Saga and Russia's Constitutional Amendments
}

\section{Introduction}

On 24 February 2020, a Dutch appeals court ${ }^{* 1}$ ruled that the Russian state owed shareholders in the company Yukos 50 billion US dollars, one of the largest sums ever awarded, for having bankrupted the company by means of tax-fraud charges. This judgement had been awaited by the international community since the District Court of The Hague ruled in Russia's favour, thereby overturning the arbitral award by the Permanent Court of Arbitration (PCA). ${ }^{*_{2}}$ In its judgement, the Court of Appeal of The Hague rejected the district court's argument pertaining to provisional application of the arbitration clause of the Energy Charter Treaty (ECT) ${ }^{*}$, including its other arguments addressing tax and investment issues. ${ }^{*}$ This international legal battle had been played out not only in front of the above-mentioned courts but also before the European Court of Human Rights (ECtHR) ${ }^{*} 5$ and various national courts of several countries, among them the United States, ${ }^{* 6}$ Belgium ${ }^{*} 7$, and France. ${ }^{*} 8$

The case of Yukos is illustrative of that part of recent Russian history in which extensive privatisation of Russian assets took place, starting in the early 1990 s and coming to an end when Vladimir Putin became

* Research for this article was supported by grant PRG969 of the Estonian Research Council.

1 The Hague Court of Appeal, on 18 February 2020. See: https://uitspraken.rechtspraak.nl/inziendocument?id=ECLI:NL:G HDHA:2020:234.

2 The PCA case: Yukos Universal Limited (Isle of Man) $v$ The Russian Federation [2014] 2005-04/AA227. https://pca-cpa. org/en/cases/61/.

3 See the material on the Energy Charter Treaty, of 17 December 1994, at: https://www.energycharter.org/process/energycharter-treaty-1994/energy-charter-treaty/, especially with regard to Article 45 (1).

4 The Hague Court of Appeal (n 1).

5 OAO Neftyanaya Kompaniya Yukos $v$ Russia, application 14902/04 (ECHR, 20 September 2011).

$6 \quad$ Richard Allen et al., Plaintiffs $v$ Russian Federation et al., Defendants, United States District Court for the District of Columbia, Civil Action 05-2077 (CKK), Memorandum Opinion of 26 November 2007. https://ecf.dcd.uscourts.gov/cgi-bin/ show_public_doc?2005cv2077-74.

7 'Tribunal de premier instance francophone de Bruxelles, section civile - 15/8181/A, 8 June 2017, jugement'. https://globalarbitrationreview.com//digital_assets/200397ed-8b57-40c6-b712-62cecc43d4bf/2017-06-08---Jugement-saisie-arrêt. pdf.

8 'Tribunal de Grande Instance à Paris, 1 December 2014, no 14/03742; Cour d'Appel de Paris, pôle 1 chambre 1, RG 15/1166, Ordonnance sur l'incident devant le magistrate chargé de la mise en charge'. https://www.italaw.com/sites/default/files/ case-documents/italaw7455.pdf. For further reading, see: Karol Bucki and Flore Poloni, 'The Yukos Case: Former Shareholders Lose Their Legal Battle in France But Continue the War' (4 December 2017). https://www.august-debouzy.com/ en/blog/1092-the-yukos-case-former-shareholders-lose-their-legal-battle-in-france-but-continue-the-war. 
the president of the Russian Federation, in 2000. When the former owner of Yukos, Mikhail Khodorkovsky, started to be politically active in Russia, the shareholders in Yukos were charged with fraud and tax evasion. With Yukos's declaration of bankruptcy, the Russian government transferred its assets to governmentowned companies. ${ }^{* 9}$

During the arbitration process, the terms of the Energy Charter Treaty ${ }^{*}{ }^{* 0}$ formed the basis for the award: the former Yukos shareholders had invoked their foreign-investment rights. Although the Russian Federation objected to the jurisdiction of the $\mathrm{PCA}^{* 11}$, that court confirmed its jurisdiction and issued the award nevertheless. ${ }^{{ }^{12}}$ After the Hague District Court then annulled the Yukos-connected arbitral award in line with Russian argumentation, that judgement was reversed by the above-mentioned Hague Court of Appeal $^{*}{ }^{*}$, so one can presume that Russia will now file a complaint against the appeals court's judgement with the Supreme Court of the Netherlands.

One key question in the legal disputes pertains to the ECT's provisional-application clause ${ }^{* 14}$, whereby an even broader question is raised - that of Russia's attitude toward international law and tribunals.

This article discusses whether non-enforcement of the arbitral award on the Russian government's part would be justified by Article 15 (1) of the Russian Constitution and what impact the currently planned amendments to the Russian Constitution might have with regard to international treaties and decisions of international bodies.

The first part of the paper deals with the Yukos case and lays out its most important facts, after which the ECT and its key function in the case will be examined. The impact of Russia's constitutional reform in particular, the proposed amendments with regard to international law - and its possible effects on the ultimate disposition of the Yukos case will be considered in the last part of the paper.

\section{The Yukos case}

With the collapse of the Soviet Union, in 1991, Russia was left struggling economically. To ensure that it would remain capable of servicing foreign debts, the Russian government made the decision to sell off state companies in parts or in their entirety in 'loans for shares' auctions. ${ }^{*} 15$ This led to several years of seemingly endless privatisation, which came to an end when Putin took office as President of the Russian Federation. Before 2000, however, the privatisation process saw Mikhail Khodorkovsky, then the owner of Menatep Bank, acquire Yukos. For purposes of promoting economic growth in poorer regions, Russia initiated a system of low-tax regions in the 1990s, under which some local authorities could either partially or completely exempt corporations in their area from corporate-profit tax. ${ }^{* 16}$ It was then that Yukos relocated to regions in Central Russia and Siberia and, later, started to sell the oil that it was extracting at a low price to its own trading companies. Those companies, in turn, resold the oil at market prices abroad. ${ }^{*}{ }^{17}$ As the Russian Federation mentioned in the course of the arbitral proceedings, ${ }^{*}{ }^{*}$ Yukos sold the oil from sham shell to sham shell for higher profits but profited from low tax rates on these sales, resulting from the location in which the trading companies had been registered.

These actions prompted the Russian Federation to accuse Yukos of tax avoidance that led to a loss of billions of dollars in Russian corporate-profit tax from 1999 to 2004. With its huge profits, the company had increased in size and by 2002 become one of the world's biggest oil companies. When Khodorkovsky

9 This laid foundations for the PCA case: Yukos Universal Limited (Isle of Man) $v$ The Russian Federation (n 2).

10 The Energy Charter Treaty (n 3).

11 See Russia's defence on appeal before the Court of Appeal in The Hague, dated 28 November 2017, at: https://www.italaw. com/sites/default/files/case-documents/italaw9634.pdf.

12 PCA, Yukos Universal Limited (Isle of Man) $v$ The Russian Federation (n 2).

13 Ibid; The Hague Court of Appeal (n 1).

14 Energy Charter Treaty (n 3) art 45 (1).

15 Stefan Hedlund, Russia's 'Market'Economy: A Bad Case of Predatory Capitalism (Routledge 1999) 189-224. DOI: https:// doi.org/10.4324/9780203495438.

16 Olivier Marquais, 'Overview of the Yukos Arbitration, International Arbitration Information' International Arbitration Attorney (19 June 2015). https://www.international-arbitration-attorney.com/overview-of-the-yukos-arbitration/ (accessed 27 April 2020).

17 Ibid.

18 PCA, 227, Final Award, para 76. https://www.italaw.com/sites/default/files/case-documents/italaw3279.pdf. 
entered merger talks with Sibneft in 2003, the proposed transaction could have made it into Russia's largest company. After merger negotiations with ExxonMobil and ChevronTexaco began, and with further growth of Khodorkovsky's political influence, the Russian government felt threatened, and Khodorkovsky was arrested on charges of fraud and tax evasion. ${ }^{*} 19$

The huge success of Yukos put the company in the spotlight. Consequently, it was perceived as one of the symbols of the privatisation of Russian industry after the dissolution of the Soviet Union, and of oligarchs enriching themselves.

Although the PCA found that Yukos had, in some respects, abused the legislation in force, it decided that the Russian Federation's reaction was far worse, in that the state 'launch[ed] a full assault on Yukos [...] in order to bankrupt Yukos and appropriate its assets while, at the same time, removing Khodorkovsky from the political arena." ${ }^{20}$

Three shareholders together owned about 70\% of Yukos and separately made three arbitration filings against the Russian Federation in early 2005 (Hulley Enterprises Limited owned 56.3\%, Yukos Universal Limited 2.6\%, and Veteran Petroleum Limited 11.6\% of Yukos Oil Company). Accordingly, three separate arbitral awards were issued, on 18 July $2014 .^{* 21}$

\section{The process of Yukos's expropriation}

The arbitral tribunal found that Russia took the following steps ${ }^{* 22}$ to expropriate the assets of Yukos. In its first action in this regard, Russia brought criminal proceedings against Yukos, which paralysed the company, and accused its directors chosen by the shareholders in Yukos Oil Company of fraud, tax evasion, and embezzlement. Next, the Russian government carried out interrogations, searches, and seizures. A further step involved a series of tax re-evaluations carried out by the Russian authorities. After those produced revisions, the tax authorities determined that Yukos owed 24 billion USD in taxes by 2006, which Yukos was not prepared to pay in such a short amount of time. The PCA's final conclusion was that 'the primary objective of the Russian Federation was not to collect taxes but rather to bankrupt Yukos and appropriate its valuable assets'. ${ }^{* 23}$ In the last step, the government seized all shares in the company and sold them off to pay the tax amounts determined for Yukos. Those shares were sold off to a sham entity that later came into the ownership of Rosneft. ${ }^{*} 24$ The tribunal noted in its award decision that this action led to the destruction of Yukos and that the assets had been sold solely to benefit the Russian state and the state-owned companies Rosneft and Gazprom. ${ }^{*} 25$

Finally, in November 2007, Yukos ceased to exist as a company.

\section{The arbitration proceedings}

The proceedings of the tribunal, which was composed of Charles Poncet, appointed by the claimant; Stephen Schwebel, appointed by the respondent; and Yves Fortier, appointed by the Permanent Court of Arbitration, were conducted under the UNCITRAL Arbitration Rules and were supervised by the PCA in The Hague. Importantly, the claims were based on the ECT. Since Article 26 of the treaty contains the terms for arbitration, investors from a particular contracting state were given the opportunity to sue either in the national courts or through arbitration.

The shareholders claimed that the measures taken by the Russian Federation had led to expropriation under article 13 of the ECT. The tribunal agreed and, therefore, stated that it did not have to decide whether Article 10's terms specifying fair and equitable treatment had been violated in addition.

19 Ibid.

20 Ibid.

21 Martin Dietrich Brauch, 'Yukos v. Russia: Issues and Legal Reasoning behind US\$50 Billion Awards' International Institute for Sustainable Development, Investment Treaty News (September 2014). https://www.iisd.org/itn/wp-content/ uploads/2014/09/iisd_itn_yukos_sept_2014_1.pdf (accessed 27 April 2020).

22 PCA (n 1) 8.

23 Ibid, para 757.

24 Ibid, para 1038.

25 Ibid, para 1180. 


\section{The ECT and Yukos}

The ECT is an energy-sector-specific multilateral treaty designed to encourage long-term co-operation with post-Soviet states in activities in the energy sector. The idea was to establish common goals for an open energy market, securing and diversifying the energy supply and stimulating cross-border investment and trade in the energy sector. ${ }^{{ }^{*} 6}$ To that end, the ECT provided for a broad scope of protection for investments. ${ }^{{ }^{*} 2}$

\section{Application of the ECT}

One important feature of the ECT is that it allows for provisional application of the treaty by a signatory, pending formal domestic ratification by that signatory. As a signatory that had not expressly indicated an inability to apply the ECT provisionally, Russia was obliged to comply with its terms prior to ratification by the Russian State Duma, 'to the extent that such provisional application is not inconsistent with its constitution, laws or regulations' in the wording of the treaty ${ }^{*} 28$

The provisional application of the treaty was judged by the PCA to be consistent with the Russian Constitution $^{* 29}$, and the court of arbitration decided that the ECT's provisional-application clause was in accordance with the rules of the Vienna Convention on the Law of Treaties (VCLT).

Article 45(1) of the $\mathrm{ECT}^{*} 30$ provides that each signatory agrees to apply the ECT provisionally with ratification pending, again 'to the extent that such provisional application is not inconsistent with its constitution, laws or regulations'. ${ }^{*}{ }^{31}$ Nevertheless, there is an ambiguity with Article 45 (2), arising from the fact that it was designed to allow a signatory nation to reject provisional application explicitly, whereupon it may excuse itself from the obligation of provisional application under Article 45 (1). Still, the Russian Federation did not invoke Article 45 (2-3), which give a signatory the right to terminate provisional application of the treaty at any time upon that signatory state's submission of written notification of its desire not to become a party to the treaty.

In the arbitration proceedings, Russia stressed that it had not ratified the ECT since doing so would have a direct effect on Russian law. Additionally, Russia stated that its public law would not allow arbitration of public matters, which include taxation and bankruptcy just as much as energy disputes. This led to the consequence that a position was maintained in Russia that the arbitration clause of the ECT could not be applied. ${ }^{*} 2$ In this regard, Russia completely ruled out provisional application of arbitration to matters of Russian public law for reason that such arbitration would be contrary to the Russian Constitution and the state's laws and regulations. Russia deemed Article 45 (1) an attempt by international law to influence national law and politics in the field of energy investment and national resources, which would be a threat to Russia's sovereignty. ${ }^{*} 3$

26 Energy Charter Treaty (n 3).

27 Ibid, art 1.

28 Energy Charter Treaty (n 3) art 45 (1); Alex M Niebruegge, 'Provisional Application of the Energy Charter Treaty: The Yukos Arbitration and the Future Place of Provisional Application in International Law' (2007) 8 Chi. J. Int'l L. 355.

29 PCA (n 1) 8, paras 314-15.

30 Article 3 of the Energy Treaty Charter (see Note 3) reads: ' 1 ) Each signatory agrees to apply this Treaty provisionally pending its entry into force for such signatory in accordance with Article 44, to the extent that such provisional application is not inconsistent with its constitution, laws or regulations. (2) (a) Notwithstanding paragraph (1) any signatory may, when signing, deliver to the Depository a declaration that it is not able to accept provisional application. The obligation contained in paragraph (1) shall not apply to a signatory making such a declaration. Any such signatory may at any time withdraw that declaration by written notification to the Depository. (b) Neither a signatory which makes a declaration in accordance with subparagraph (a) nor Investors of that signatory may claim the benefits of provisional application under paragraph (1). (c) Notwithstanding subparagraph (a), any signatory making a declaration referred to in subparagraph (a) shall apply Part VII provisionally pending the entry into force of the Treaty for such signatory in accordance with Article 44, to the extent that such provisional application is not inconsistent with its laws or regulations. (3) (a) Any signatory may terminate its provisional application of this Treaty by written notification to the Depository of its intention not to become a Contracting Party to the Treaty. Termination of provisional application for any signatory shall take effect upon the expiration of 60 days from the date on which such signatories written notification is received by the Depository.(...)'

31 Energy Charter Treaty (n 3) art 45 (1).

32 Halil Rahman Basaran, 'What To Make of the Yukos v. Russia Dispute?' (2019) 22(1) Gonzaga Journal of International Law 10869, 2.

33 Ibid. 
Nevertheless, the arbitral tribunal decided that the Russian Federation must accept an 'all or nothing' approach to provisional application since by signing the treaty Russia had agreed to apply it as a whole. ${ }^{*} 34$ Furthermore, the tribunal concluded that provisional application is not in conflict with Russian law and that Russia was, in fact, subject to provisional application of 45 other treaties at the time of the arbitration. ${ }^{*}{ }^{35}$ In accordance with the principle of good faith, states may only remove inconsistencies, not introduce new ones.

The tribunal's conclusions reiterated that the award underscores the principles of the VCLT and emphasises the pacta sunt servanda ${ }^{* 36}$ principle.

The predominant view in Russia is that investor-state disputes are not matters of public law but private-law disputes. ${ }^{*}{ }^{37}$ Russian lawyers argued before the Dutch appeals court that the parts of the ECT providing for arbitration did not apply and that the PCA had no jurisdiction. However, the PCA ruled that it did, because 'such provisional application' refers to application of a treaty as a whole, including the parts about arbitration. ${ }^{*} 38$

\section{Possible need for modernisation of the ECT}

In 2009, the Russian Federation not only decided to terminate provisional application of the ECT ${ }^{*} 39$ but also stated its intention of not becoming a contracting party to the ECT and thus not ratifying it. Nevertheless, Russia put forward its 'Conceptual Approach' in the same year to demonstrate its discontentment with the existing frameworks for bilateral and multilateral co-operation. ${ }^{*} 40$ In a document titled 'Roadmap for EU-Russia Energy Cooperation until 2015*41, Russia pronounced its interest with regard to energy goals shared between the EU and Russia in the form of a multilateral agreement.

Questions regarding regulation of transit are crucial for Russia and in the context of the ECT could make the Energy Charter Treaty interesting to the country again. ${ }^{*} 42$ According to the Heritage Foundation, ${ }^{*} 43$ a conservative think-tank in the USA, levels of property-rights protection remain low there (although there has been a slight improvement over the years) and this is one more reason for Russia to reconsider ratification of the ECT - doing so could attract investment to the Russian energy industry. ${ }^{*} 4$

In 2019, the Council of the European Union mandated that the European Commission start negotiations for modernisation of the ECT. ${ }^{*} 45$ The intention behind this is not only to include additional protection measures aimed at sustainable development and addressing climate issues but also to clarify and modernise the standards of investment protection applied, especially mechanisms for resolution of investorstate disputes. This should improve legal certainty and lead to stronger investment protection. ${ }^{*} 6$ More

34 Yukos Universal Ltd. $v$ Russian Federation (n 2) para 301.

35 Ibid, paras 330-37.

36 Ibid, paras 312-15.

37 See: Lauri Mälksoo, Russian Approaches to International Law (OUP 2015) 127. DOI: https://doi.org/10.1093/acprof: oso/9780198723042.001.0001.

38 This is addressed in the PCA's Yukos Universal Limited (Isle of Man) $v$ The Russian Federation (n 2); for further reading, consult: Johannes Fahrer, 'A New Hope for the Yukos Shareholders - PCA Awards Revived by the Hague Court of Appeal' EJIL: Talk! (4 March 2020). https://www.ejiltalk.org/a-new-hope-for-the-yukos-shareholders-pca-awards-revived-by-thehague-court-of-appeal/ (accessed 28 April 2020).

39 Decree of the Government of the Russian Federation 1055-p, of 30 July 2009.

40 'Conceptual Approach to the New Legal Framework for Energy Cooperation' (21 April 2009) per material in Russian at: http://www.kremlin.ru/supplement/258.

41 Russian Federation, 'Roadmap for EU-Russia Energy Cooperation until 2015' (March 2013) per Russian-language material at: https://russiaeu.ru/sites/default/files/user/Roadmap\%20Russia-EU\%20Energy\%20Cooperation\%20until\%202050_Rus. pdf.

42 Irina Pominova, 'Risks and Benefits for the Russian Federation from Participating in the Energy Charter: Comprehensive Analysis' (Energy Charter Secretariat Knowledge Centre 2014). https://www.energycharter.org/fileadmin/DocumentsMedia/ Occasional/Russia_and_the_ECT_en.pdf.

43 Heritage Foundation, '2020 Index of Economic Freedom - Russia'. https://www.heritage.org/index/country/russia.

44 Pominova (n 42).

45 European Council, 'Council Adopts Negotiation Directives for Modernisation of Energy Charter Treaty' (15 July 2019). https:// www.consilium.europa.eu/en/press/press-releases/2019/07/15/council-adopts-negotiation-directives-for-modernisationof-energy-charter-treaty/.

46 Ibid. 
specifically, it would cover most-favoured-nation (MFN) treatment provisions, fair and equitable treatment (FET), matters connected with expropriation (direct or indirect), umbrella clauses, transfers (allowing free transfers relative to investment), and denial of benefits for purposes of maintaining international peace and security. ${ }^{*} 47$

Although modernisation of the ECT represents a lengthy process, involving many members having to come to agreement, this step would be necessary for clarifying the application of certain clauses and preventing further misunderstandings pertaining to interpretation of precisely the sort that occurred in the Yukos case. In any case, any future modernisation of the treaty cannot affect past investment disputes, such as that related to Yukos. Nevertheless, they could make the treaty attractive again for Russia. This, in turn, would create a platform for negotiations in the energy sector and clarify the ECT's application.

\section{Russia's constitutional reform in relation to international treaties and its impact on the Yukos case}

\section{The Anchugov and Gladkov case}

Already in 2015, the Russian Federation made amendments to the Federal Constitutional Law in aims of strengthening the supremacy of the Russian Constitution over international law. ${ }^{*} 48$ On 4 July 2013, the ECtHR issued a decision on Anchugov and Gladkov $v$. Russia*49, in response to a case in which the Russian Constitutional Court had been asked by a member of the State Duma to carry out control for purposes of determining the mutual compatibility of ECtHR rulings and the Russian Constitutional order. ${ }^{*} 5^{\circ}$ In the Anchugov and Gladkov case, the ECtHR decided that the Russian Federation had violated Article 3 of Protocol 1 to the European Convention on Human Rights (ECHR) in that it denied convicted prisoners the right to vote. Said article was in direct conflict with Article 32 (3) of the Russian Constitution, ${ }^{*}{ }^{1}$ which deprives prisoners of the right to vote or to be elected to public office. The Russian Constitutional Court responded by issuing a decision on 19 April 2016, ${ }^{*}{ }^{2}$ which it proceeded to cite with regard to implementation of the ECtHR's rulings in this case. This decision laid out the foundation for a new line of reasoning of the Russian Constitutional Court, which had been made possible by a 14 July 2015 decision of the same court, in which it held the possibility of not or only partially executing judgments of the ECHR if they were considered contrarty to the Russian Constitution. Some of the dissatisfaction with the reasoning of the ECtHR may well have been connected with the award granted by the ECtHR in the Yukos case. ${ }^{*} 53$ In any case, with the April 2016 ruling, the Russian Constitutional Court set the direction for more 'autonomous' interpretation of Russian law with regard to international matters and pulled Russia away from the general European understanding of human rights as reflected in the ECHR. ${ }^{*} 54$

\footnotetext{
47 'Approved Topics for the Modernisation of the Energy Charter Treaty' (6 October 2019). https://www.energychartertreaty. org/modernisation-of-the-treaty/.

48 The Russian Federation's Federal Law 7-ФКЗ, 'Federal Law on the Introduction of Amendments to the Federal Constitutional Law "On the Constitutional Court of the Russian Federation"', approved by the State Duma on 4 December 2015 and by the Federation Council on 9 December 2015 and entering into force on 14 December 2015.

49 Anchugov and Gladkov $v$ Russia, applications 1157/04 and 15162/05 (ECHR, 4 July 2013).

50 Lauri Mälksoo, 'Russia's Constitutional Court Defies the European Court of Human Rights: Constitutional Court of the Russian Federation Judgment of 14 July 2015, No 21-П/2015’ (2016) 12(2) European Constitutional Law Review 377-95. DOI: https://doi.org/10.1017/s1574019616000237.

51 The Constitution of the Russian Federation's Article 32 (3) states: 'Deprived of the right to elect and be elected shall be citizens recognized by court as legally unfit, as well as citizens kept in places of confinement by a court sentence.'

52 The decision on ECtHR cases 1157/04 and 151662/05 (Anchugov and Gladkov), of 19 April 2016. See: http://doc.ksrf.ru/ decision/KSRFDecision258613.pdf and http://doc.ksrf.ru/decision/KSRFDecision230222.pdf.

53 Marina Aksenova, 'Anchugov and Gladkov Is Not Enforceable: The Russian Constitutional Court Opines in Its First ECtHR Implementation Case' Opinio Juris (25 April 2016). http://opiniojuris.org/2016/04/25/anchugov-and-gladkov-is-notenforceable-the-russian-constitutional-court-opines-in-its-first-ecthr-implementation-case/ (accessed 27 April 2020).

54 Ibid.
} 
With non-payment of the amount awarded by the ECtHR by the deadline given by the Court, 15 March $2015^{*}{ }^{55}$, along with other non-enforcement of judgements, ${ }^{*}{ }^{6}$ the Russian Federation leads in terms of ECtHR Judgment non-enforcement. This might be linked to a lack of political will on the part of the government. ${ }^{*} 57$

\section{Amendments to the Russian Constitution}

During his annual speech addressed to the Federal Assembly on 15 January 2020, President Putin announced that he sees a need to amend the Russian Constitution. Hence, on 20 January 2020, he presented a draft law titled 'On Improving Regulation of Certain Issues of the Organization of Public Authority' ${ }^{\text {" }} 8$ to the State Duma, which turned the draft into law three days later.

Article 15 of the Russian Constitution states ${ }^{*} 59$ in its first paragraph that 'the Constitution of the Russian Federation has the highest legal force' but then adds in paragraph 4 that 'generally recognized principles and norms of international law and international treaties of the Russian Federation are an integral part of its legal system'. Article 15 (4) continues: 'If an international treaty or agreement of the Russian Federation fixes other rules than those envisaged by law, the rules of the international agreement shall be applied.' Until the decision in Anchugov and Gladkov ${ }^{*} 60$, the common understanding of this article seemed quite clear as to the priority of international law. Nevertheless, when one considers Article 15 as a whole alongside Russia's later decision on non-enforcement of certain awards issued by international tribunals, there are indications that the Russian Constitution has the highest legal force in Russia. Therefore, the Russian Constitution takes precedence over international law.

The proposed amendments ${ }^{*} 61$ to the Russian Constitution would directly affect this, as President Putin has proposed an amendment to 'guarantee the priority of the Constitution in Russian legal space'. 62 That amendment would necessitate changes to what is currently Article 15 of the Constitution, which is part of its Chapter I, a portion to be redrafted only by the Constitutional Assembly. In a further complication, there is no law on this body on the books at present, so it is not currently possible to establish a Constitutional Assembly. ${ }^{*} 63$

This proposed amendment sends a signal that can be understood as announcing how Russia will deal with unfavourable international judgements in the future. ${ }^{*} 64$ The proposed change seems only symbolic, especially since the Russian Constitutional Court has already pronounced (in the Anchugov and Gladkov case) how it plans to deal with decisions that it judges incompatible with the Russian Constitution.

55 Council of Europe, Department for the Execution of Judgments of the European Court of Human Rights, 'Information Relating to Payment Awaited or Information Received Incomplete, Status As of 20 July 2020' OAO Neftyanaya Kompaniya Yukos $v$ Russian Federation 19. https://rm.coe.int/09000016805a9af7.

56 Ibid, 10-25.

57 Mälksoo (n 50) 394

58 Draft law of the Russian Federation: Законопроект, 885214-7. https://sozd.duma.gov.ru/bill/885214-7.

59 Constitution of the Russian Federation, art 15: '1. The Constitution of the Russian Federation shall have the supreme juridical force, direct action[,] and shall be used on the whole territory of the Russian Federation. Laws and other legal acts adopted in the Russian Federation shall not contradict the Constitution of the Russian Federation. 2. The bodies of state authority, the bodies of local self-government, officials, private citizens and their associations shall be obliged to observe the Constitution of the Russian Federation and laws. 3. Laws shall be officially published. Unpublished laws shall not be used. Any normative legal acts concerning human rights, freedoms and duties of man and citizen may not be used, [sic] if they are not officially published for general knowledge. 4. The universally-recognized norms of international law and international treaties and agreements of the Russian Federation shall be a component part of its legal system. If an international treaty or agreement of the Russian Federation fixes other rules than those envisaged by law, the rules of the international agreement shall be applied.'

60 Russian Constitutional Court (n 52).

61 By the Duma per Federal Meeting of the Russian Federation: 'Что изменится в Конституции? (Chto izmenitsya v Konstitutsii?)' (What Will Change the Constitution?). http://duma.gov.ru/news/47985/.

62 See: https://www.interfax.ru/russia/691265.

63 Yulia Ioffe, 'The Amendments to the Russian Constitution: Putin's Attempt To Reinforce Russia's Isolationist Views on International Law?' EJIL: Talk! (29 January 2020). https://www.ejiltalk.org/the-amendments-to-the-russian-constitutionputins-attempt-to-reinforce-russias-isolationist-views-on-international-law/ (accessed 27 April 2020).

64 Ibid. 
Furthermore, this amendment could serve as justification for Russia's decision in the Yukos case ${ }^{*} 65$, since the Russian Constitutional Court has stated that such compensation would violate the provisions of the Russian Constitution. ${ }^{* 66}$ The above-mentioned decision might be oriented toward future disputes, especially those related to the current situation on the Crimean Peninsula ${ }^{*} 67$ and pending investment lawsuits. ${ }^{* 68}$

Under Russian law, international treaties that are incompatible with the Russian Constitution may not be signed and ratified by the Russian Federation. This entails application of its Article $79^{* 69}$, under which membership in an international body would not be allowed if that body's principles are not in line with the Russian Constitution. Therefore, the question of Russia's membership in the Council of Europe arises, especially in conditions of potentially introducing an amendment to the Russian Constitution that would even strengthen the principle of adopting constitutional distance from the ECHR. With formalisation of the power of the Russian Constitutional Court to decide whether or not the state need enforce decisions or awards specified by foreign jurisdictions and arbitral courts, Russia's membership in international organisations would no longer be very meaningful. After all, there would openly exist the option of Russia not recognising a decision of, for example, the ECtHR.

\section{The impact on implementation of the PCA's Yukos Award}

In this light, the Yukos dispute demonstrates the prominence and pride of place of governments in the functioning and enforcement of international law and, in at least this case, the realm of international investment law and arbitration. With official amendment to the Russian Constitution and, thereby, the Russian interpretation of international law, the number of international judgements that Russia might try to dismiss as irrelevant could grow. This step would dislodge Russian international law from international law and already agreed-upon treaties as they are understood in the West.

If, nevertheless, new amendments to the Russian Constitution were used as justification for nonenforcement of the PCA's Yukos award, that action would go against the international principle of legal certainty and non-retroactivity. Also, a parallel can be drawn to the current legal situation in Ukraine. The Ukrainian state has already brought several complaints against Russia before international tribunals - not only the ECtHR and the International Court of Justice (ICJ) but also the International Criminal Court (ICC), with regard to the situation in Eastern Ukraine. Furthermore, Ukrainian investors have initiated several filings for investor-state arbitration themselves. ${ }^{*} 70$ Against this backdrop, there is ample significance of the ease with which, via amendments to the Russian Constitution, Russia could ignore decisions by international tribunals in the future.

65 Russian Constitutional Court decision on ECtHR case 14902/04 (Yukos), of 19 January 2017, per: ttp://doc.ksrf.ru/decision/KSRFDecision258613.pdf.

66 Ibid, 8-9, 22, and 25.

67 Of tensions between the two countries since Russia's annexation of the Crimean Peninsula in 2014.

68 Current and pending investment-law cases involving disputes on the Crimean Peninsula. See, among other materials: 'PCA Press Release: PJSC Ukrnafta v. The Russian Federation and Stabil LLC et al. v. The Russian Federation' (24 April 2019) on application 2015-34. https://pca-cpa.org/en/news/pca-press-release-pjsc-ukrnafta-v-the-russian-federation-and-stabilllc-et-al-v-the-russian-federation-5/; 'PCA Press Release: Aeroport Belbek LLC and Mr. Igor Valerievich Kolomoisky v. The Russian Federation' (15 February 2019) on application 2015-07. https://pca-cpa.org/en/news/pca-press-release-aeroportbelbek-llc-and-mr-igor-valerievich-kolomoisky-v-the-russian-federation-4/; 'PCA Press Release: JSC CB PrivatBank and Finance Company Finilon LLC v. the Russian Federation' (15 February 2019) on ongoing proceedings from application 2015-21. https://pca-cpa.org/en/news/pca-press-release-jsc-cb-privatbank-and-finance-company-finilon-llc-v-the-russianfederation/.

69 Constitution of the Russian Federation, art 79: 'The Russian Federation may participate in interstate associations and transfer to them part of its powers according to international treaties and agreements, if this does not involve the limitation of the rights and freedoms of man and citizen and does not contradict the principles of the constitutional system of the Russian Federation.'

70 Examples are provided by the PCA's: PJSC Ukrnafta $v$ The Russian Federation and Stabil LLC et al. $v$ The Russian Federation (n 68); Aeroport Belbek LLC and Mr Igor Valerievich Kolomoisky $v$ The Russian Federation (n 68); SC CB PrivatBank and Finance Company Finilon LLC $v$ The Russian Federation (n 68). 


\section{Conclusion}

No country, to date, has been able to enforce the Yukos arbitral award against Russia. The arbitration tribunal in the Yukos investment case ruled in favour of the company, affirming that provisional application of the ECT was compatible with Russian domestic law. Still, Russia regards the matter as an issue of sovereignty and sees its power as being threatened. First and foremost, the Yukos award involves so much money that any country would probably be reluctant to 'lose'.

The proposed amendments to the Russian Constitution might seem only symbolic but form part of efforts to lay a foundation for Russia's selective compliance with decisions of international tribunals and with international law in general. This is especially concerning with regard to the proposed precedence of the Russian Constitution over international treaties and decisions by international bodies. The amendments would directly assure the priority of the Russian Constitution in the Russian legal system and over international law. That would, in turn, result in the Russian Constitution dictating that international treaties and decisions of international bodies cannot be valid on Russian territory if they contradict the Constitution of the Russian Federation. These efforts do not exist in isolation. Recall that the Russian Parliament passed a law already in 2015 empowering the Russian Constitutional Court to declare decisions of international human-rights bodies non-enforceable when such decisions are incompatible with the Russian Constitution.

In regard of the Yukos case, the proposed amendments should not be of impact if they come to pass, since law should not be modified retroactively. We should keep in mind also that Article 27 of the VCLT stipulates that '[a] party may not invoke the provisions of its internal law as justification for its failure to perform a treaty'. One can assume that this encompasses reinterpretation of a state constitution and constitutional law, because these are still part of domestic law, even if the highest law of the land. Therefore, political and theory-oriented debate will continue and it is likely to remain hard for the former Yukos shareholders to collect their money under the PCA's arbitral award - especially since on 15 May 2020 the Russian Federation submitted an appeal ${ }^{*} 71$ in cassation at the Dutch Supreme Court against the judgement of the Hague Court of Appeal ${ }^{*} 72$.

71 Reuters (Tom Balmforth), 'Russia Appeals \$57 Billion Yukos Payout in Dutch Supreme Court' (20 May 2020). https:// www.reuters.com/article/netherlands-russia-yukos/russia-appeals-57-billion-yukos-payout-in-dutch-supreme-courtidUSL8N2CX2QH.

72 The Hague Court of Appeal (n 1). 